\title{
Tissue-specific pattern of variant transcripts of the human gonadotropin-releasing hormone receptor gene
}

\author{
Marie-Laure Kottler ${ }^{1,2}$, Françoise Bergametti ${ }^{1}$, Marie-Claude Carré ${ }^{1}$, Sylvie Morice ${ }^{1}$, Evelyne Decoret ${ }^{1}$, \\ Jean-Pierre Lagarde ${ }^{2}$, Anna Starzec ${ }^{3}$ and Raymond Counis ${ }^{1}$ \\ ${ }^{1}$ Endocrinologie Cellulaire et Moléculaire de la Reproduction, ESA CNRS 7080, Université Pierre et Marie Curie, 75005 Paris, France, \\ ${ }^{2}$ Service de Biochimie Médicale, Unité de Génétique Moléculaire, AP-HP Pitié-Salpêtrière, 75013 Paris, France and ${ }^{3}$ Institut d'Oncologie Cellulaire et \\ Moléculaire Humaine, 93000 Bobigny, France \\ (Correspondence should be addressed to M-L Kottler, Endocrinologie Cellulaire et Moléculaire de la Reproduction, Université Pierre et Marie Curie, \\ ESA CNRS 7080, case 244, 75252 Paris Cedex 05, France)
}

\begin{abstract}
The expression pattern of the GnRH receptor was investigated in a variety of normal and neoplastic human tissues by RT-PCR-Southern blotting. In addition to the full-length cDNA (sb1), we identified two other transcripts: the first (sb2) was characterized by a 128 bp deletion as previously described; the second was an unexpected finding composed of a shorter cDNA (sb3), the sequence of which revealed a $220 \mathrm{bp}$ deletion corresponding in size to exon 2 . These three transcripts were found in normal pituitary and pituitary adenomas, and in granulosa tumors, but not in testis, where sb2 was lacking. Only sb1 was expressed in normal, fibrocystic and malignant breast tissue. No transcript with a full-length region was found in endometrium, intestine or lymphocytes. This is the first report that shows that splicing of the gonadotropin-releasing hormone receptor gene is tissue dependent.

We also determined the intron-exon nucleotide sequence of the gene and identified an MaeIII polymorphic site in exon 1 created by a silent C453T transition found in $10 \%$ of unrelated French whites.
\end{abstract}

European Journal of Endocrinology 140 561-569

\section{Introduction}

Gonadotropin-releasing hormone (GnRH) is a decapeptide that plays a central role in the neurohormonal control of reproduction, by stimulating the synthesis and release of the pituitary gonadotropins, luteinizing hormone (LH) and follicle-stimulating hormone (FSH), which in turn promote development of gonadal functions. The neuropeptide activates high-affinity membrane receptors (GnRHR) belonging to the G-protein-coupled receptor family. The human GnRHR consists of 328 amino acids. cDNAs encoding a functional pituitary GnRHR have been obtained in mice $(1,2)$, rats (3), humans $(4,5)$ and sheep $(6)$, and predicted amino acid sequences were highly conserved among the species. The coding region is distributed among three exons separated by two large introns $(7,8)$. The human gene has been mapped to chromosome 4 (9), between the markers D4S312 and D4S409 (10).

Given its central role in the regulation of gonadotropin secretion, GnRHR may possibly be implicated, directly or indirectly, in putative pathological processes such as a lower $(11,12)$ or higher $(13,14)$ production of gonadotropins or alteration of their regulation. We therefore determined the nucleotide sequences of introns flanking the exon boundaries in order to design three sets of primers in the intronic sequences to study the GnRHR at the DNA level.

We have identified three different mRNA species for the receptor (15). The largest form corresponded to the full-length GnRHR sequence. The shortest was obtained by alternative splicing of exon 2 and was also found in mice (16). The putative encoded protein was composed of only 177 amino acids. The third transcript contained a partial deletion of $128 \mathrm{bp}$ and arose from the use of an alternative acceptor site within exon 2 . This deletion causes a frame shift, thereby generating a new truncated protein of 249 amino acids; $Q^{174}$ is followed by a stretch of 75 new amino acid residues that substitutes for the corresponding 154 amino-acid sequence previously reported. In vitro studies have suggested that this new variant may interact with the full-length $\mathrm{GnRH}$ receptor and impair signaling by reducing agonist-induced accumulation of inositol phosphate (17). In humans, controversial data have been obtained relating to the presence of extrapituitary GnRH-binding sites in breast $(18,19)$, placenta (20), ovaries (21) and testis (22). Northern blot analysis failed to detect GnRHR mRNAs in any of the nonpituitary tissues examined (5). However, using a reverse 
transcriptase-polymerase chain reaction (RT-PCR) protocol, these mRNAs were recently identified in granulosa-luteal cells (23), endometrial and ovarian tumors $(24,25)$, prostate $(25)$ and breast $(25,26)$ tumors. Data suggested that, in cancer cells, GnRH analogs may interfere with mitogenic signal transduction (27).

The relative abundance of GnRHR isoforms, through regulation of splicing, may be of critical importance in modulating the biological effect of GnRH. When the proteins encoded by spliced variants are functionally critical, splicing has proved to be a source of functional diversity (28). The present study was undertaken to examine the expression of the human GnRHR gene in different healthy or neoplastic tissues, by means of highly sensitive RT-PCR-Southern blotting analysis with different primer sets, and to determine the tissue distribution of the different GnRHR transcripts. The physiological relevance of extrapituitary GnRHR may thereby be clarified.

\section{Materials and methods}

\section{Human tissue collection}

Tissue specimens from normal pituitary and testis were collected at autopsy. Other specimens were obtained at surgery and subjected to a pathological analysis: one non-secreting and four gonadotropinsecreting pituitary adenomas; endometrium specimens from neoplastic disease (three cases) and from noncarcinologic disease (one case); breast biopsy specimens from fibrocystic disease (three cases), from carcinomas (five cases) including one adjacent non-neoplastic fragment and granulosa tumors (three cases). Intestine fragments and lymphocytes were used as non-endocrine tissue controls. After removal, a portion of each tissue was rapidly dissected, deep frozen in liquid nitrogen, and stored at $-70^{\circ} \mathrm{C}$ until required for RNA extraction. Granulosa cells were collected from preovulatory follicles obtained from patients who received an injection of D-Trp ${ }^{6}-\mathrm{GnRH}$ (triptorelin-LP, $3.75 \mathrm{mg}$ ), and then human menopausal gonadotropin and 5000 IU human chorionic gonadotrophin (hCG).

\section{RNA extraction and RT-PCR}

Total RNA was extracted according to Chomczynski \& Sacchi (29) using RNA-B (Bioprobe Systems, Montreuil, France). RNA was transcribed into DNA using either random hexanucleotide primers and Moloney murine leukemia virus (M-MLV) reverse transcriptase (GibcoBRL, Paris, France) or pdT primers and Super-Script II reverse transcriptase (Gibco-BRL). This cDNA was used as a template for PCR amplifications as previously described (30) using 0.3 U Taq Polymerase (Eurogentec, Seraing, Belgium). Thirty cycles were performed at $95^{\circ} \mathrm{C}, 55^{\circ} \mathrm{C}$, and $72{ }^{\circ} \mathrm{C}$ for $50 \mathrm{~s}$ each. Each PCR mixture $(7 \mu \mathrm{l})$ was electrophoresed on agarose gel $(1 \%)$ with
DNA markers and stained with ethidium bromide. Forward (F) and reverse (R) oligonucleotide primer (Genset, Paris, France) nomenclature and sequence are listed in Fig. 1 and their position indicated with reference to the human GnRHR cDNA sequence previously published $(4,5)$. A negative control, in which cDNA was replaced by water, was systematically added in each run.

When PCR failed to amplify a specific DNA sequence, PCR for $\beta$ actin was performed to exclude the possibility of RNA degradation or RNA transcription default. Primers were derived from the DNA sequence (31):

A1F: 5'-CCCAGATCATGTTTGAGACC-3' A2R: 5'-CGCTCATTGCCGATAGTGAT-3'

\section{Southern blot hybridization}

The identity of the DNA generated by PCR was confirmed by Southern blot analysis. PCR products in agarose gels were alkaline transferred to nylon membranes (Hybond-N, Amersham, les Ulis, France) and hybridized using the technique of Moumni et al. (30). A 1006 bp human GnRHR cDNA (10) was used as a probe for Southern blot hybridization.

\section{Cloning and nucleotide sequence determination of PCR products}

After purification, PCR products were cloned in pUC 18 and sequenced using the Sequenase Sequencing System version 2.0 (USB, Amersham, Cleveland, USA) as previously described (30).

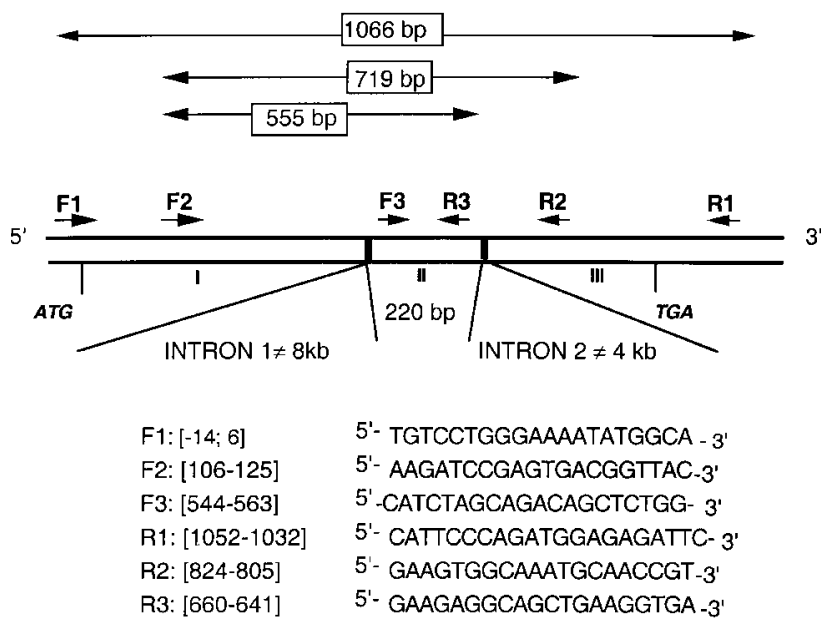

Figure 1 Schematic representation of the GnRHR gene showing position of introns within the open reading frame. Location and orientation of sense $(F)$ and antisense $(R)$ primers within the exonic map are depicted as black arrows. Their corresponding sequence and position are shown below and the sizes of the PCR products indicated above. 


\section{Genomic amplification of the introns and sequencing}

The intronic regions were amplified from $300 \mathrm{ng}$ human DNA, with the Expand Long Template PCR System (Boehringer Mannheim, Meylan, France). Primers were chosen to bridge each of the introns described $(7,8)$ : F2/R3 spans from exon 1 to exon 2 and F3/R2 spans from exon 2 to exon 3. Manufacturers' recommendations were followed, with adapted modifications. Briefly, 33 cycles of amplification were carried out in Tris- $\mathrm{HCl} 50 \mathrm{mmol} / \mathrm{l}(\mathrm{pH} 9),\left(\mathrm{NH}_{4}\right)_{2} \mathrm{SO}_{4} 14 \mathrm{mmol} / \mathrm{l}$; $\mathrm{MgCl}_{2} 2.25 \mathrm{mmol} / \mathrm{l}$ using $0.75 \mu \mathrm{l}$ enzyme mix containing thermostable Taq and Pwo DNA polymerases. One cycle included denaturation at $93^{\circ} \mathrm{C}$ for $25 \mathrm{~s}$ and annealing at $55^{\circ} \mathrm{C}$ for $30 \mathrm{~s}$. The elongation step was performed at $68^{\circ} \mathrm{C}$. The elongation time was $10 \mathrm{~min}$ for the first 11 cycles and it was then increased by $40 \mathrm{~s}$ every three cycles. PCR aliquots $(15 \mu \mathrm{l})$ were analyzed by $0.8 \%$ agarose electrophoresis. The identity of the DNA generated by PCR was subsequently confirmed by Southern blot analysis. Products $(600 \mathrm{ng})$ obtained from three different normal subjects were purified on Microcon-30 columns (Amicon, Beverly, MA, USA) and sequenced directly using the AmpliTaq dye Terminator Cycle Sequencing kit and an ABI PRISM 377 DNA sequencer (Perkin Elmer, Roissy, France).

\section{Results}

\section{Nucleotide sequence of the GnRHR gene}

Figure 2 shows PCR products of genomic DNA of approximately $8 \mathrm{~kb}$ using F2/R3 (lane 1) and $4 \mathrm{~kb}$ using F3/R2 (lane 2). Southern blot hybridization using the GnRHR cDNA probe attested to the identity of the products, which corresponded to amplification of intron 1 and intron 2 respectively.

The nucleotide sequence of the human GnRH receptor gene is shown in Fig. 3; positions and sequences of intronic primers used for subsequent DNA amplification of the coding region of the gene are indicated. Exon 1 displays a silent $\mathrm{C}$ to $\mathrm{T}$ transition at nucleotide 453 , which is a part of a codon for a serine residue, situated in the second intracellular loop at position 151. The C453T transition created a new MaeIII site within exon 1 (14). The allele frequency of the former polymorphism was evaluated in DNA extracted from lymphocytes (genomic DNA) obtained from 92 healthy unrelated French Caucasians. Seventeen subjects (18.4\%) were heterozygous for the C453T transition, and only one subject (1\%) was homozygous.

\section{Identification of variant GnRHR cDNA sequences in human pituitary gland}

Figure 4 shows an agarose gel analysis of RT-PCR fragments amplified from human pituitary gland using

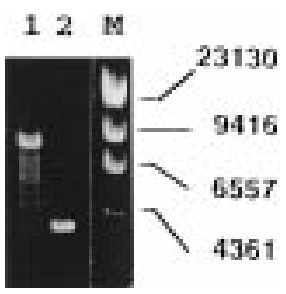

Figure 2 Amplification products of human genomic DNA using F2/R3 (lane 1) and F3/R2 (lane 2). DNA markers (M) (lambda digested with HindIII) and products were electrophoresed in $0.8 \%$ agarose and stained with ethidium bromide.

primer pairs F1/R1. The three fragments, designated $\mathrm{sb} 1, \mathrm{sb} 2$ and $\mathrm{sb} 3$, were generated, the sizes of which were approximately 1060, 930 and 840 bp respectively. Every fragment hybridized with $\left[{ }^{32} \mathrm{P}\right] \mathrm{GnRHR}$ cDNA probes. PCR products were purified separately from gels and their nucleotide sequences were carefully determined after cloning in pUC 18 . The sequence of $\mathrm{sb1}$ was identical to that of the previously reported human GnRHR $(4,5)$. Sequence analysis of the shorter fragment, sb3, revealed an identical nucleotide sequence, with the notable exception of a $220 \mathrm{bp}$ deletion located between nucleotides 523 and 742 . The deleted sequence corresponds to exon 2 and occurs exactly at the same position. This deletion shifts the open reading frame, and immediately downstream is a translation termination codon. Thus the generated mRNA encodes for a protein of only 177 amino acids (Fig. 5), deleted for the putative transmembrane domains TIV-TVII, and the hydrophilic extracellular (E) and intracellular (I) loops (E2, E3 and I3 respectively).

sb2 exhibits a sequence identical to that of sb1, but with a shorter deletion of $128 \mathrm{bp}$ beginning at nucleotide 523, similar to sb3, but finishing at nucleotide 650. The partial deletion of exon 2 and the subsequent alteration of the reading frame yields a putative protein of 249 amino acids in which $Q^{174}$ is followed by a stretch of 75 new amino acid residues. The former take the place of the different 154 amino acid sequence previously reported and correspond to the sequence described by Grosse et al. (17). These three variants of the GnRHR transcript were PCR-generated from pituitary gland using either pdN6 or pdT as primers for the reverse transcription step, without notable variation in the expression status.

\section{Extrapituitary expression of GnRHR}

In order to determine the distribution of the GnRHR variants, we studied a variety of tissues including breast, testis, ovary, uterus, intestine and lymphocyte. We used F2/R2 primers encompassing the open reading frame from exon 1 to exon 3. The predicted size of the PCR-amplified GnRHR DNA was 719 bp for the fulllength transcript (sb1), 499 bp for the exon 2-lacking 
$-26$ $\frac{\text { ggcttg aagctctgtc ctgggaaaat }}{\text { EI-S }}$

$1 / 1$

$31 / 11$

ATG GCA AAC AGT GCC TCT CCT GAA CAG AAT CAA AAT CAC TGT TCA GCC ATC AAC AAC AGC

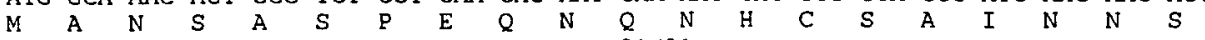
61/21
ATC CCA CTG ATG CAG GGC AAC CTC CCC ACT CTG ACC TTG TCT GGA AAG ATC CGA GTG ACG $\begin{array}{lllllllllllllllllllll}I & P & L & M & Q & G & N & L & P & T & L & T & L & S & G & K & I & R & V & T\end{array}$ $121 / 41$

GTT ACT TTC TTC CTT TTT CTG CTC TCT GCG ACC TTT AAT GCT TCT TTC TTG TTG AAA CTT $\begin{array}{llllllllllllllllllll}\mathrm{V} & \mathrm{T} & \mathrm{F} & \mathrm{F} & \mathrm{L} & \mathrm{F} & \mathrm{L} & \mathrm{L} & \mathrm{S} & \mathrm{A} & \mathrm{T} & \mathrm{F} & \mathrm{N} & \mathrm{A} & \mathrm{S} & \mathrm{F} & \mathrm{L} & \mathrm{L} & \mathrm{K} & \mathrm{L}\end{array}$ $181 / 61 \quad 211 ; 71$

CAG AAg TGG ACA CAG AAG AAA GAG AAA GGG AAA AAG CTC TCA AGA ATG AAg CTG CTC TTA $\begin{array}{llllllllllllllllllll}Q & K & W & T & Q & K & K & E & K & G & K & K & L & S & R & M & K & L & L & L\end{array}$ $241 / 81 \quad 271 / 91$

AAA CAT CTG ACC TTA GCC AAC CTG TTG GAG ACT CTG ATT GTC ATG CCA CTG GAT GGG ATG

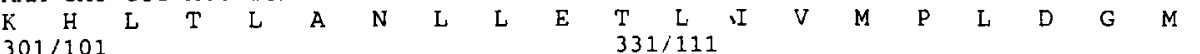
TGG AAC ATT ACA GTC CAA TGG TAT GCT GGA GAG TTA CTC TGC AAA GTT CTC AGT TAT CTA

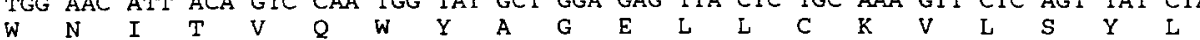
$391 / 131$
AAG CTT TTC TCC ATG TAT GCC CCA GCC TTC ATG ATG GTG GTG ATC AGC CTG GAC CGC TCC $\begin{array}{llllllllllllllllllll}\mathrm{K} & \mathrm{L} & \mathrm{F} & \mathrm{S} & \mathrm{M} & \mathrm{Y} & \mathrm{A} & \mathrm{P} & \mathrm{A} & \mathrm{F} & \mathrm{M} & \mathrm{M} & \mathrm{V} & \mathrm{V} & \mathrm{I} & \mathrm{S} & \mathrm{L} & \mathrm{D} & \mathrm{R} & \mathrm{S}\end{array}$ 421/141 451/151

CTG GCT ATC ACG AGG CCC CTA GCT TTG AAA AdC AAC AGC AAA GTC GGA CAG TCC ATG GTT

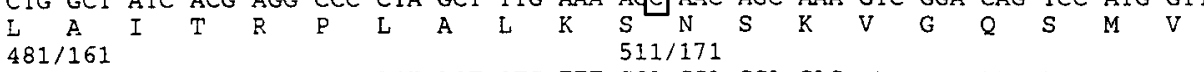
GGC CTG GCC TGG ATC CTC AGT AGT GTC TTT GCA GGA CCA CAG gtaagccatt atacacaaac $G \quad L \quad A \quad W \quad I \quad L \quad S \quad S \quad V \quad F \quad A \quad G \quad P \quad Q$

ttattggat atggtgatca tagatttcct atctaattt gatataaggt cttatcaaag gaagtactgt attacctta aaacttggg ttctggaagt cacaagtgaa gtttaatctg gctctgttct gttaccttgg q - - - - - - - - - - - - - - - - - cactaagga gctragaat tgcttraggt aacatgttag aaggctagca gagtaccaaa gagaaactt

\begin{tabular}{cccc}
\hline E2-S & $523 / 175$ & \\
tcaaatacca tatggaaaa agtaacatag cttttattg tctcatacag TTA TAC ATC TTC AGG ATG
\end{tabular}

$541 / 181 \quad 571 / 191$ $571 / 191$ TCT $\begin{array}{lllllllllllllllll}\text { ATT CAT CTA } & \text { GCA } & \text { GAC AGC TCT } & \text { GGA } & \text { CAG } & \text { ACA } & \text { A } & \text { V } & F & S & Q & C & V & T & H & C\end{array}$

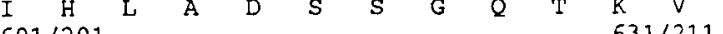
AGT TTT TCA CAA TGG TGG CAT CAA GCA TTT TAT AAC TOTT TTC ACC TTE AGC TGC CTC TTC

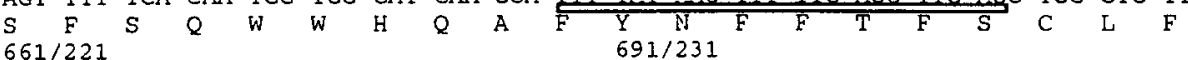

ATC ATC CCT CTR TTC ATC ATG CTG ATC TGC AAT GCA AAA ATC ATC TTC ACC CTG ACA CGG

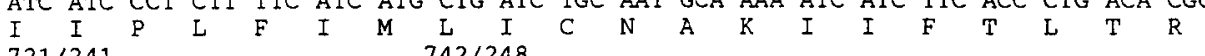
$721 / 241 \quad 742 / 248$ GTC CTT CAT CAG GAC CCC CAC G gtatgtattc cttagagtta gtgtcatttg tgggcagttt ttaa $\begin{array}{llllllll}\mathrm{L} & \mathrm{H} & \mathrm{Q} & \mathrm{D} & \mathrm{P} & \mathrm{H} & \mathbf{E} & -\mathrm{R}\end{array}$ -

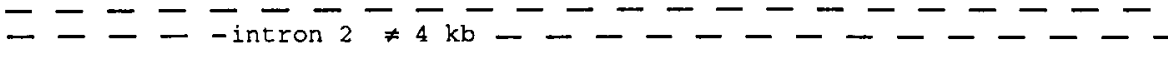
gatta agttgattag gatgctgtet tcctettgt ccacttggt tttgtaagaa aactgatct taaac acctg ctctetctc tatccaacag AA CTA CAA CTG AAT CAG TCC AAG AAC AAT ATA CCA AGA $\begin{array}{lllllllllllllll}781 / 261 & E & L & Q & L & N & Q & S & K & N & N & I & P & R\end{array}$ GCA CGG CTG AAG ACT CTA AAA ATG ACG GTT GCA TTT GCC ACT TCA TTT ACT GTC TGC TGG $\begin{array}{lllllllllllllllllllll}A & R & L & K & T & L & K & M & T & V & A & F & A & T & S & F & T & V & C & W\end{array}$ $841 / 281 \quad 871 / 291$ ACT CCC TAC TAT GTC CTA GGA ATT TGG TAT TGG TTT GAT CCT GAA ATG TTA AAC AGG TTG $\begin{array}{llllllllllllllllllll}T & P & Y & Y & V & L & G & I & W & Y & W & F & D & P & E & M & L & N & R & L\end{array}$ $901 / 301 \quad 931 / 311$ TCA GAC CCA GTA AAT CAC TTC TTC TTT CTC TTT GCC TTT TTA AAC CCA TGC TTT GAT CCA $\begin{array}{llllllllllllllllllll}S & \mathrm{D} & \mathrm{P} & \mathrm{V} & \mathrm{N} & \mathrm{H} & \mathrm{F} & \mathrm{F} & \mathrm{F} & \mathrm{L} & \mathrm{F} & \mathrm{A} & \mathrm{F} & \mathrm{L} & \mathrm{N} & \mathrm{P} & \mathrm{C} & \mathrm{F} & \mathrm{D} & \mathrm{P}\end{array}$ $961 / 321$

CTT ATC TAT GGA TAT TTT TCT CTG TGA trgatagazt acacaagaag tcatatgaag aagggtaagg L I $Y$ G Y F S L *

taatgaatct ctccatctgg gaatgattaa cacaatgtt ggagcatgtt tacatacaa caaagtagga tttacactta agttatcatt ctttragaa sfcagtct to agacacctca attattaagg aaagctctt R1

caggaaaat actaaatat tectctcct cataagctc taattaatc tctgccttt ctgacctcat ataacacatt atgtaggttt cttatcactt tctcttgca taataatgta ctaatattra aaataccttc agcctaaggc acaaggargc caaaaaaca aaggegagaa accacaacac aggtctaaac tcagcatgct trggtgagtt tttctccaaa aggggcatat tagcaattag agttgtatgc tatataatac atagagcaca gagccetttg cccataátat caactttccc tcctatagt aaaaaaaaa aaaaaa

Figure 3 Nucleotide sequence of the human $\mathrm{GnRH}$ receptor gene, showing intron-exon bundaries. The coding region of exons are presented in upper-case letters and non-translated regions are depicted in lower-case letters. Nucleotides of the transcripts are numbered from the translational start site. The stop codon is marked with an asterisk. Primers used for DNA amplification are underlined and their orientation depicted by an arrow. The Maelll site is boxed. The $3^{\prime}$ consensus acceptor site within exon 2 is double-underlined. Sequence data have been deposited with EMBL/GenBank data libraries under accession numbers Z99760, Z99761, Z99995. 


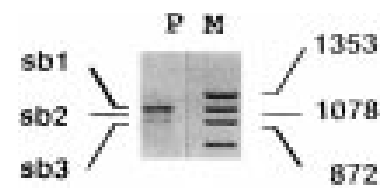

Figure 4 Agarose (1\%) electrophoresis of products obtained from RT-PCR of RNA extracted from a human pituitary $(P)$ using F1/R1. $\mathrm{M}$ represents migration of DNA markers (Phi X-174 digested with HaellI). The gel was stained with ethidium bromide.

variant (sb3) and $591 \mathrm{bp}$ for the partial exon 2-deleted variant (sb2) (Fig. 6A, B, lanes P). The size of PCRamplified GnRHR DNA with F2/R3 was 555 bp (see Fig. 1). The identity of each PCR product was confirmed by subsequent Southern blot analysis. We demonstrated that GnRHR mRNA was present in human testis (Fig. 6A, lane 1), in one of three granulosa tumors (lane $\mathrm{G}$ ) and in all breast tissues that were positive for actin amplification (Fig. 6B), including breast cancer (lanes 2-5, 8), fibrocystic disease (lanes 6, 7) and normal breast tissues (lane 9). No amplified material appeared in uteri, intestine or leucocytes. Furthermore, PCR amplification of $\beta$ actin excluded the possibility of RNA degradation in these tissues (data not shown).

The presence of the three GnRHR mRNA species varied among the tissues. In breast tissue, we demonstrated the presence of only the full-length transcript (Fig. 6B lanes 2-9), whereas a doublet was visualized in testis, consistent with the expression of the fulllength transcript and the exon 2-lacking variant (Fig. 6A lane 1). In one of three granulosa tumours (Fig. 6A lane $\mathrm{G}$ ), the three mRNA species were detected. In contrast, in uterus (Fig. 6C, lanes 10-13) and intestine (Fig. 6C lanes 14, 15), amplification with F2/R3 demonstrated the presence of a single form of mRNA through the amplification of the first two exons; use of $F 3 / R 2$, however, failed to amplify fragments from exon 2 to exon 3 (data not shown). Finally, no signal was found in lymphocyte samples (Fig. 6C, lane 16).

\section{Discussion}

Using primers designed to match exon sequences, we amplified two very large introns of approximately $8 \mathrm{~kb}$ and $4 \mathrm{~kb}$ and each exon-intron boundary sequence was determined. We identified a silent polymorphism at nucleotide 453 (14), different from that recently described by Grosse et al. (17) at nucleotide 150 in exon 1 and creating an MaeIII restriction site. The observed heterozygosity was low (18\%) and was in agreement with the Hardy-Weinberg equilibrium. This polymorphism may be a useful tool for further segregation analysis in humans, as was recently described in hypogonadotropic hypogonadism $(11,12)$.

\section{Identification of different mRNA transcripts of the GnRHR gene in pituitary}

Because the RT-PCR yield obtained from human pituitary with F1/R1 was very low, other sets of primers were tested in order to optimize the PCR conditions. To improve the specificity of the PCR product, primers $\mathrm{R} 2 / \mathrm{F} 2$ were chosen according to the octamer frequency disparity method (33) using PC-Rare software (Eurogentec).
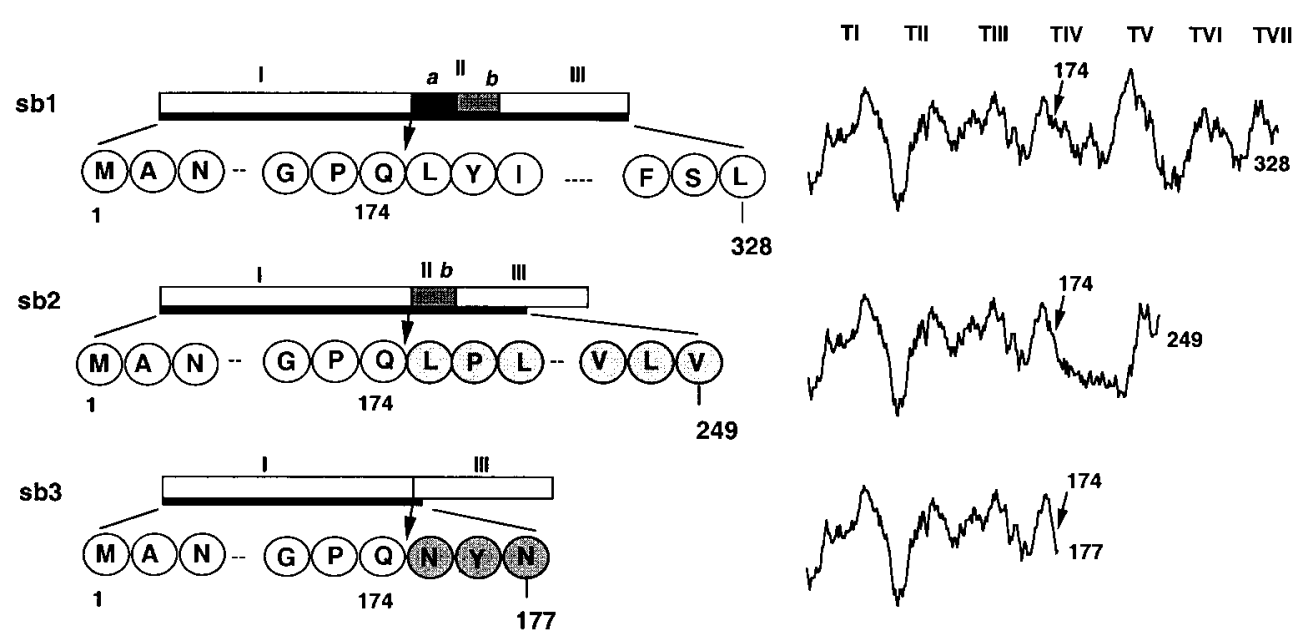

249

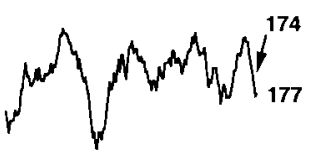

Figure 5 Schematic representation of the three variants, sb1, sb2 and sb3, showing the position of exons 1,2 and 3 (shown here as I, II and III), and the corresponding predicted peptide sequences (presented in the one-letter code). Exon II is divided into two parts named $a$ and $b$. Ila contains the $3^{\prime}$ consensus acceptor site. The arrow indicates the position of exon I-exon II boundary and the begining of the amino acid differences at the C-terminal domain. sb1 corresponds to the full-length transcript, sb2 is exon-lla deleted, and sb3 contains only exon I and exon III. The open reading frame is indicated by black boxes. Analysis for hydrophobicity (32) of sb1 and the putative sb2 and sb3 proteins is also represented, at the right. TI-TVII, transmembrane domains. 
A

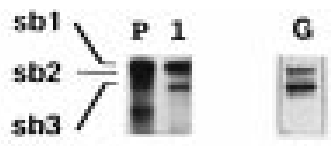

B 719

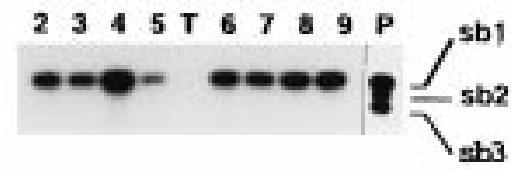

C 555

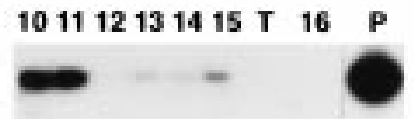

Figure 6 PCR amplification of the first strand CDNA from various tissues, followed by Southern blotting and hybridization with a ${ }^{32} \mathrm{P}$-labeled GnRHR cDNA probe. The PCR primers were F2/R2 (see Fig. 1) for panels $A$ and $B$, and F2/R3 for panel C. The expected sizes are indicated on the left. sb1, sb2 and sb3 correspond to amplification of normal, partially and totally exon-2-deleted variants respectively. Pituitary (lanes $\mathrm{P}$ ), testis (lane 1), tumor granulosa cells (lane $\mathrm{G}$ ), ductal infiltrative breast cancer (lanes 2-5, 8), fibrocystic breast disease (lanes 6, 7) and normal breast tissue (lane 9), healthy endometrium (lane 10) and neoplasic endometria (lanes 11-13), neoplasic intestine (lanes 14-15) and leucocytes (lane 16).

We report the detection by RT-PCR of three forms of GnRHR mRNA in the human pituitary. These transcripts were identified from cDNA obtained using random primers and pdT, suggesting that they are polyadenylated and not processing intermediates.

The organization of the gene, with two very large introns in the coding frame, supports the possibility that exon 2 may be alternatively spliced. Our finding is strengthened by the description of an alternative transcript of the GnRHR gene in a mouse pituitary tumor cell line cDNA library (16); among 42 clones, two (4.7\%) contained only exons 1 and 3, encoding a truncated protein of 177 amino acids, similar to our findings.

Concerning the other PCR product, sb2, its $5^{\prime}$ coding region was identical to that of the GnRHR gene. Sequence analysis clearly indicated partial deletion of exon 2 at the spliced junction with exon 1 . While we were preparing our manuscript, this transcript was described by Grosse et al. (17), who used the same RT-PCR protocol. Although the mechanism of mRNA splicing is not well understood, the most probable splicing signal for generation of $\mathrm{sb} 2$ was a nearly perfect $3^{\prime}$ consensus acceptor splice site $5^{\prime}$-(Py)nNCAGC- $3^{\prime}$ found within the exon 2 sequence (between nucleotides 628 to 650 , with reference to the translation initiation codon). This putative splicing signal has been shown to be present in sheep (6) and in rats $(3,4)$, but was absent in mice $(1,2)$ in which the $3^{\prime}$ intron boundary AG signal is lacking. Although partial deletion of an exon is an unusual feature, it has been described in the mouse CREB (cAMP responsive element binding protein) gene (34): the variant, pmcCREBX, contains a modification of exon 10 and a variable sequence at its $3^{\prime}$ end, which leads to a modification of the C-terminal amino acid residues. The deletion shifts the reading frame and generates an mRNA encoding a protein of 249 amino acids, of which the last 75 totally differ from the previously described GnRHR. Homology searches in sequence banks failed to reveal any known protein sequences closely related to this C-terminal domain. However, five putative casein kinase II phosphorylation sites (35) were identified.

Similar results were found with the growth hormonereleasing hormone receptor (GHRHR) $(36,37)$ and it has been suggested that the expression of variant forms of GHRHR mRNA may be part of the oncogenic process that results in pituitary adenomas (36). Although analysis of the GnRHR gene expression by RT-PCR was not quantitative, we observed the three variants in normal pituitary gland in addition to tumors. It may therefore be concluded that alternative splicing of GnRHR probably does not lead to oncogenesis, and the process of oncogenesis does not lead to alternative splicing.

Whether these transcripts were indeed translated in vivo has remained uncertain. The truncated protein encoded by the $\mathrm{sb} 2$ variant in eukaryotic cells, was shown to be inserted within the membrane, but it does not respond to challenge with agonist. When co-expressed with wild-type (WT) using excess of cDNA (4- to 15-fold more than the WT cDNA), the splice variant has a specific and dose-dependent inhibitory effect on signal transduction initiated by the fulllength activated receptor (17). Moreover, it reduced the cell surface expression of the WT receptor. The putative sb3 isoform was constituted by only three transmembrane domains, and a truncated TIV. It was deleted of a region which, in addition to contributing to the structure, contains amino acid residues indispensable for binding GnRHR (38). Consequently, it is expected that, like sb2, sb3 has no binding activity and thus no transductional activity. Whether sb3 interferes (like sb2, albeit in non-physiological conditions) with sb1 function remains unknown.

\section{Gene expression of GnRHR in various human tissues}

We took advantage of our RT-PCR data in the pituitary gland to investigate the expression of GnRHR gene in extrapituitary human tissues. We demonstrated the presence of GnRHR transcript in human testis. Bourne et al. (22) reported that high-affinity binding sites for GnRH are present in Leydig cells but not in Sertoli cells, and the presence of GnRHR mRNA has been demonstrated in rat testis (30). These results strongly support the existence of a GnRHR in human testis, identical to that in the pituitary. We also detected the transcript in one of the three granulosa tumors, but we were unable to amplify full-length GnRHR sequences 
from follicular cells obtained from women undergoing in vitro fertilization. Minaretzis et al. (39) amplified GnRHR cDNA sequences spanning exons 1 and 2 in human ovary. As we have demonstrated in uterus and intestine, this procedure does not provide evidence that a full-length mRNA is transcribed. In contrast, Peng et al. (23) documented expression and regulation of GnRHR in human granulosa-luteal cells obtained from patients undergoing in vitro fertilization, but provided no information about the hormonal therapy received by these women. Our negative results may be explained by the use of $\mathrm{GnRH}$ agonists, which suppressed gonadotropin secretion in our group of patients. Indeed, we have demonstrated that, in rats, GnRH agonist markedly alters pituitary GnRHR gene expression leading to a rapid, time-dependent decrease in the mRNA levels (40). In addition, Peng et al. (23) showed that treatment with high doses of GnRH or hCG downregulated GnRHR gene expression in cultured human granulosa-luteal cells. We were unable to confirm the presence of full-length GnRHR mRNA in endometria as described by Imai et al. (24). Although sequences from exon 1 to exon 2 were amplified in our study, sequences from exon 2 to exon 3 were not. The present transcript may be related to the mouse cDNA clones obtained by Zhou \& Sealfon (16), which contained exons 1 and 2 and, in addition, contained genomic sequence of intron 2 . Using the reverse primer, E2-R, designed within intron 2, we were unable to obtain a PCR product and our study does not confirm the presence of a similar transcript. The findings of Ikeda et al. (41) confirm these data, with the report that GnRH, but not its receptor, is expressed in human endometrium and decidua. However, GnRHR expression was recently found in $30 \%$ of endometrial samples analyzed from fertile women (42). Finally, we confirmed expression of the GnRHR gene in both malignant and non-malignant human breast tissues, as previously described $(25,26)$.

Whereas Grosse et al. (17) consistently failed to detect the truncated splice variant in cells of extrapituitary origin, we found that different forms of GnRHR mRNA were expressed in human gonads: the full-length transcript, in addition to the variant lacking exon 2 in the testis; and the three spliced variants in granulosa tumor cells. Only the transcript with the full-length coding sequence appeared to be present in human breast tissues.

In conclusion, this paper demonstrates the ubiquitous expression of the GnRHR gene in human tumor or non-tumor reproductive tissues, with variable presence of the different GnRHR transcripts among tissues. We suggest that GnRHR splicing may be regulated in a tissue-specific manner, or under specific hormonal or metabolic conditions. Generation of protein isoforms by alternative splicing is known to occur in numerous members of the G-protein-coupled receptors family $(28,34,43)$, correlating with differences in affinity, potency, coupling efficiency, specificity, subcellular localization or sensitivity to desensitization of the receptor. Differential splicing could also have a physiological significance, as production of short transcript was shown to downregulate the levels of WT transcript (44). In this manner, regulation of splicing may introduce another level of control in the expression of the GnRHR gene in pituitary and extrapituitary human tissues.

\section{Acknowledgements}

This work was supported by a grant from the Direction à la Recherche Clinique, CRC 96108.

The authors are indebted to Prof. A Warnet (Service de Médecine Interne, Hôpital Lariboisière, Paris, France), Drs F Peillon (INSERM U 223, Paris), S Carreau (IBBA, Caen, France) and C Guettier, A Martin and Mrs M Guil (Service d'Anatomie Pathologique, Hôpital Avicenne, Bobigny, France), Prof. J R Zorn (Service de Gynécologie-Obstétrique, Hôpital Cochin, France) and Prof. J M Bidart (Institut Gustave Roussy, Villejuif, France) for providing human biopsy specimens. Human lymphocyte mRNA was kindly provided by Prof. F Sigaux (Service d'Hématologie, Hôpital Saint-Louis, Paris) from a blood library. We are grateful to P Commerçon (Laboratoire de Biochimie Endocrinienne et Moléculaire, Faculté de Pharmacie, Lyon, France) for computer analysis.

Part of this research was presented at the 10th International Congress of Endocrinology, San Francisco (Abstract P3-252).

Sequence data have been deposited with EMBL/ GenBank data libraries under accession numbers Z99760, Z99761, Z99995.

\section{References}

1 Reinhart J, Mertz LM \& Catt KJ. Molecular cloning and expression of cDNA encoding the murine gonadotropin-releasing hormone receptor. Journal of Biological Chemistry $199226721281-$ 21284.

2 Tsutsumi M, Zhou W, Millar RP, Mellon PL, Roberts JL, Flanagan CA et al. Cloning and functional expression of a mouse gonadotropin-releasing hormone receptor. Molecular Endocrinology 19926 1163-1169.

3 Eidne KA, Sellar RE, Couper G, Anderson L \& Taylor PL. Molecular cloning and characterization of the rat pituitary gonadotropin-releasing hormone $(\mathrm{GnRH})$ receptor. Molecular and Cellular Endocrinology 199290 R5-R9.

4 Kakar SS, Musgrove LC, Devor DC, Sellers JC \& Neill JD. Cloning, sequencing, and expression of human gonadotropin-releasing hormone (GnRH) receptor. Biochemical and Biophysical Research Communications 1992189 289-295.

5 Chi L, Zhou W, Prikhozhan A, Flanagan C, Davidson JS, Golembo $\mathrm{M}$ et al. Cloning and characterization of the human GnRH receptor. Molecular and Cellular Endocrinology 199391 R1-R6.

6 Brooks J, Taylor PL, Saunders PTK, Eidne KA, Struthers WJ \& McNeilly AS. Cloning and sequencing of the sheep pituitary gonadotropin-releasing hormone receptor and changes in 
expression of its mRNA during the estrous cycle. Molecular and Cellular Endocrinology 199394 R23-R27.

7 Fan NC, Peng C, Krisinger J \& Leung PCK. The human gonadotropin-releasing hormone receptor gene: complete structure including multiple promoters, transcription initiation sites, and polyadenylation signals. Molecular and Cellular Endocrinology $1995107 \mathrm{R} 1-\mathrm{R} 8$

8 Kakar S. Molecular structure of the human gondotropin-releasing hormone receptor gene. European Journal of Endocrinology 1997 137 183-192.

9 Fan NC, Jeung EB, Peng C, Olofsson JI, Krisinger J \& Leung PCK. The human gonadotropin-releasing hormone (GnRH) receptor gene: cloning, genomic organization and chromosomal assignment. Molecular and Cellular Endocrinology 1994103 R1-R6.

10 Kottler M-L, Lorenzo F, Bergametti F, Commerçon P, Souchier C \& Counis R. Subregional mapping of the human gonadotropinreleasing hormone receptor (GnRHR) gene to $4 \mathrm{q}$ between the markers D4S392 and D4S409. Human Genetics 199596 477-480.

11 De Roux N, Young J, Misrahi M, Genet R, Chanson P, Schaison G \& Milgrom E. A family with hypogonadotropic hypogonadism and mutations in the gonadotropin-releasing hormone receptor. New England Journal of Medicine 1997337 1597-1602.

12 Layman LC, Cohen D, Jin M, Xie J, Li Z, Reindollar RH et al. Mutations in gonadotropin-releasing hormone receptor cause hypogonadotropic hypogonadism. Nature Genetics 199818 14-15.

13 Kaye PV, Hapgood J \& Millar RP. Absence of mutations in exon 3 of the GnRH receptor in human gonadotroph adenomas. Clinical Endocrinology 199747 549-554.

14 Kottler ML, Seret-Bégué D, Lahlou N, Assayag M, Carré MC, Lagarde JP et al. The GnRH receptor gene is preferentially expressed in functioning gonadotroph adenomas and displays a Mae III polymorphism site. Clinical Endocrinology $199849115-$ 123.

15 Kottler ML, Bergametti F, Carré MC, Starzec A \& Counis R. Alternative splicing and tissue distribution of transcripts for human gonadotropin-releasing hormone receptor. In: Program and Abstract of the 10th International Congress of Endocrinology, San Francisco, CA, 12-15 June 1996. Abstract P3-252. Bethesda, MD, USA: Endocrine Society Press.

16 Zhou W \& Sealfon SC. Structure of the mouse gonadotropinreleasing hormone receptor gene: variant transcripts generated by alternative processing. DNA Cell Biology 199413 605-614.

17 Grosse R, Schöneberg T, Schultz G \& Gudermann T. Inhibition of gonadotropin releasing hormone receptor signaling by expression of a splice variant of the human receptor. Molecular Endocrinology 199711 1305-1318.

18 Eidne KA, Flanagan CA \& Millar RP. Gonadotropin-releasing hormone binding sites in human breast carcinoma. Science 1985 229 989-991.

19 Miller WR, Scott WN, Morris R, Fraser HM \& Sharpe RM. Growth of human breast cancer cells inhibited by a luteinizing hormonereleasing hormone agonist. Nature 1985313 231-233.

20 Iwashita M, Evans MI \& Catt KJ. Characterization of a gonadotropin-releasing hormone receptor site in term placenta and chorionic villi. Journal of Clinical Endocrinology and Metabolism 198662 127-133.

21 Latouche J, Crumeyrolle-Arias M, Jordan D, Kopp N, AngendreFerrante B, Cedar L \& Haour F. GnRH receptors in human granulosa cells: anatomical localization and characterization by autoradiographic study. Endocrinology 1989125 1739-1741.

22 Bourne GA, Regiani S, Payne AH \& Marshall JC. Testicular GnRH receptors - characterization and localization on interstitial tissue. Journal of Clinical Endocrinology and Metabolism 198051 407-409.

23 Peng C, Fan NC, Ligier M, Väänänen J \& Leung PCK. Expression and regulation of gonadotropin-releasing hormone (GnRH) and GnRH receptor messenger ribonucleic acids in human granulosaluteal cells. Endocrinology 1994135 1740-1746.
24 Imai A, Ohno T, Iida K, Fuseya T, Furui T \& Tamaya T. Gonadotropin-releasing hormone receptor in gynecologic tumors - frequent expression in adenocarcinoma histologic types. Cancer 199474 2555-2561.

25 Kakar SS, Grizzle W \& Neill JD. The nucleotide sequences of human GnRH receptors in breast and ovarian tumors are identical with that found in pituitary. Molecular and Cellular Endocrinology 1994106 145-149.

26 Kottler ML, Starzec A, Carre MC, Lagarde JP, Martin A \& Counis R. The genes for gonadotropin-releasing hormone and its receptor are expressed in human breast with fibrocystic disease and cancer. International Journal of Cancer 199771 595-599.

27 Emons G, Muller V, Ortmann O \& Schulz KD. Effects of LHRHanalogues on mitogenic signal transduction in cancer cells. Journal of Steroid Biochemistry and Molecular Biology 199865 199-206

28 Journot L, Spengler D, Pantaloni C, Dumuis A, Sebben M \& Bockaert J. The PACAP receptor: generation by alternative splicing of functional diversity among $G$ protein-coupled receptors in nerve cells. Seminars in Cell Biology $19945263-$ 272.

29 Chomczynski P \& Sacchi N. Single-step method of RNA isolation by acid guanidinium thiocyanate-phenol-chloroform extraction. Analytical Biochemistry 1987162 156-159.

30 Moumni M, Kottler ML \& Counis R. Nucleotide sequence analysis of mRNAs predicts that rat pituitary and gonadal gonadotropinreleasing hormone receptor proteins have identical primary structure. Biochemical and Biophysical Research Communications $19942001359-1366$.

31 Nudel U, Zakut R, Shani M, Neuman S, Levy Z \& Yaffe D. The nucleotide sequence of the rat cytoplasmic $\beta$-actin gene. Nucleic Acids Research 198311 1759-1771.

32 Kyte J \& Doolittle RF. A simple method for displaying the hydropathic character of a protein. Journal of Molecular Biology 1982157 105-132.

33 Giffais R, André PM \& Thibon M. K-tuple frequency in the human genome and polymerase chain reaction. Nucleic Acids Research $1991193887-3891$.

34 Ruppert S, Cole TJ, Boshart M, Schmid E \& Schutz G. Multiple mRNA isoforms of the transcription activator protein CREB: generation by alternative splicing and specific expression in primary spermatocytes. EMBO Journal 199211 1503-1512.

35 Pinna LA. Casein kinase 2: an eminence grise in cellular regulation? Biochimica et Biophysica Acta 19901054 267-284.

36 Tang J, Lagacé G, Castagné J \& Collu R. Identification of human growth hormone-releasing hormone receptor splicing variants. Journal of Clinical Endocrinology and Metabolism 199580 2381-2387.

37 Hashimoto K, Koga M, Motomura T, Kasayama S, Kouhara H, Ohnishi $\mathrm{T}$ et al. Identification of alternatively spliced messenger ribonucleic acid encoding truncated growth hormone-releasing hormone receptor in human pituitary adenomas. Journal of Clinical Endocrinology and Metabolism 199580 2933-2939.

38 Zhou W, Flanagan C, Ballesteros JA, Konvicka K, Davidson JS, Weinstein $\mathrm{H}$ et al. A reciprocal mutation supports helix 2 and helix 7 proximity in the gonadotropin-releasing hormone receptor. Molecular Pharmacology 199410 979-986.

39 Minaretzis D, Jakubowski M, Mortola JF \& Pavlou SN. Gonadotropin-releasing hormone receptor gene expression in human ovary and granulosa-lutein cells. Journal of Clinical Endocrinology and Metabolism 199580 430-434.

40 Lerrant Y, Kottler M-L, Bergametti F, Moumni M, Blumberg-Tick J \& Counis R. Expression of GnRH receptor gene is altered by GnRH agonist desensitization in a manner similar to that of gonadotropin beta subunit genes in normal and castrated rat pituitary. Endocrinology 1995136 2803-2808.

41 Ikeda M, Taga M, Kurogi K \& Minaguchi H. Gene expression of gonadotropin-releasing hormone, but not its receptor, in human endometrium and decidua. Molecular and Cellular Endocrinology $1997135165-168$. 
42 Raga F, Casan EM, Kruessel JS, Wen Y, Huang HY, Nezhat C \& Polan ML. Quantitative gonadotropin-releasing hormone gene expression and immunohistochemical localization in human endometrium throughout the menstrual cycle. Biology of Reproduction $199859661-669$.

43 Dal Toso R, Sommer B, Ewert M, Herb A, Pritchett DB, Bach A et al. The dopamine $\mathrm{D}_{2}$ receptor: two molecular forms generated by alternative splicing. EMBO Journal 19898 4025-4034.
44 Sparks K, Mayer S \& Dieckmann C. Premature 3' end formation of CBP1 mRNA results in downregulation of cytochrome b mRNA during the induction of respiration in Saccharomyces cerevisiae. Molecular and Cellular Biology 199717 4199-4207.

Received 23 September 1998

Accepted 8 March 1999 